\title{
A Study Regarding Bacterial Contamination of Surfaces in Dental Offices
}

\author{
Kyoung-Ok Yun ${ }^{1}$ and Hye-Young Kim $^{2}$ \\ ${ }^{1}$ Department of Dental Hygienics, Shinsung University, Dangjin 31801, Korea \\ ${ }^{2}$ Department of Clinical Laboratory Science, Shinsung University, Dangjin 31801, Korea
}

\section{치과진료실 내 표면 세균 오염에 관한 연구}

\author{
윤경옥 ${ }^{1}$, 김예영 ${ }^{2}$ \\ 신성대학교 ${ }^{1}$ 치위생과, ${ }^{2}$ 임상병리과
}

\begin{abstract}
This study studied samples taken off surfaces at three sites (Unit chairs, light handles, cuspidors) of 19 dental hospitals and 28 clinics located in Gyeonggi-do and Incheon, South Korea. The bacterial contamination levels of surfaces were $44.82 \times 10^{3} \mathrm{CFU} / \mathrm{mL}$ in cuspidors, higher than in unit chairs $\left(5.47 \times 10^{3} \mathrm{CFU} / \mathrm{mL}\right)$ and light handles $\left(16.28 \times 10^{3} \mathrm{CFU} / \mathrm{mL}\right)$. The values were statistically higher at dental hospitals than at dental clinics, the greater number of patients being associated with the higher bacterial cell count in the cuspidors. The results of identifying the strains isolated purely from surfaces at dental clinic showed Gram positive $47.3 \%$ and Gram negative $52.7 \%$. Among Gram positive, the most numberous bacteria were Micrococcus luteus (10.9\%), Bacillus pumilus (3.6\%), and Staphylococcus aureus (3.6\%). Among Gram negative, the most numberous bacteria were Acinetobacter ursingii (5.5\%), Brevundimonas diminuta (4.5\%), Chryseobacterium (Flavo.) indologenes (CDC IIb) (4.5\%), and Methylobacterium sp. (4.5\%). This study measures the level of bacterial contamination and identifies the strains isolated in dental clinics. It recognizes the importance of infection control, and the results of the study may be considered as the basis for establishing specific plans for prevention of infection.
\end{abstract}

Keywords: Bacterial contamination, Cuspidors, Dental clinics, Dental hospitals, Unit chairs

This is an Open Access article distributed under the terms of the Creative Commons Attribution Non-Commercial License (http://creativecommons.org/licenses/by-nc/4.0) which permits unrestricted non-commercial use, distribution, and reproduction in any medium, provided the original work is properly cited.

Copyright (ㅇ 2015 The Korean Society for Clinical Laboratory Science. All rights reserved.
Corresponding author: Hye-Young Kim Department of Clinical Laboratory Science, Shinsung University, Dangjin 31801, Korea Tel: 82-41-350-1407

E-mail: khy@shinsung.ac.kr

Received: October 16, 2015 Revised $1^{\text {st. }}$ November 2, 2015

Revised $2^{\text {nd }}$ : November 5, 2015

Revised 3 ${ }^{\text {rd: }}$ November 6, 2015

Revised $4^{\text {th }}$ : November 8, 2015

Accepted: November 8, 2015

\section{서 론}

최근 원내 감염에 대한 인식이 높아지면서 의료기관의 병원감염 관리 시스템의 중요성과 문제점에 대한 관심이 집중되고 있다. 또 한 의료기관의 인증평가나 임상 질 지표 평가 기준에서도 감염관리 에 대한 비중이 높아지고 있다. 하지만 이러한 노력에도 면역기능 저하 환자와 노인 - 장기이식환자의 증가, 항생제 내성균주의 증가 및 침습적 시술의 보편화 등으로 인하여 의료관련 감염이 계속 발
생되고 있다(Yun, 2014).

특히, 치과 진료실의 환경은 치료 시 날카로운 기구로 조직을 뚫 고 들어가 구강 내 출혈을 발생시키고, 이때 환자의 혈액과 세균 및 바이러스를 포함하고 있는 타액이 침투하여 감염성 질환을 발생시 킨다는 보고가 있다(Eom과 Kim, 2012). 그리고 핸드피스나 초음 파 스케일러 등의 사용으로 감염인자와 독소물질을 포함한 에어로 졸이 발생되어 제한된 공간을 계속 순환하며 떠다니다가 낙하되어 진료실을 오염시키기 때문에 치과 의료진뿐만 아니라 환자에게도 
감염증을 일으키게 된다. 또한 의료진과 환자의 감염은 진료 환자 나 가족 등에게도 수평적, 수직적 감염을 일으키는 매개체 또는 감 염경로의 역할을 한다는 부분에서 중요시 되고 있다(Leggat 등, 2007).

치과 진료실에서 교차감염의 위험이 있는 감염성 질환으로는 $\mathrm{B}$ 형 - C형 간염, 결핵, 포진, 구강과 상기도 감염질환이며, 최근에는 $\mathrm{HIV}$ 바이러스 출현으로 인한 후천성 면역결핍증의 감염 경로가 된 다는 보고가 강조되고 있다(Centers for Disease Control and Prevention, 2003; Jamshid 등, 2012).

이에 2006년 7월 보건복지부에서는 치과진료실의 “치과진료 감 염방지 기준’을 제정하여 실천함으로써 진료실의 위생수준 향상과 교차 감염을 방지하는 감염예방에 노력하기 시작하였으며(Lee, 2013), 한국보건사회연구원과 보건복지가족부 주관으로 2007년 부터 2009년까지 치과 의료기관평가 시범사업에 '감염관리' 항목 을 포함 시키게 되었다(Shin, 2008). 하지만 이러한 노력에도 불구 하고 치과의료 종사자들의 감염관리에 대한 인식도가 낮고, 실천 부족으로 감염의 위험성은 더욱 증가되고 있으며, 특히 치과 진료 실 내 세균 오염도에 대한 연구와 감염 질환 원인균에 대한 조사가 부족한 실정이다.

이에 본 연구는 병원 - 의원 치과 진료실 내 세균 오염도를 측정 하고, 감염 질환의 원인이 될 수 있는 세균을 확인함으로써 적극적 인 감염관리의 중요성을 인식시키고, 감염방지를 위한 구체적인 방 법을 계획 수립하기 위한 기초자료를 제시하고자 한다.

\section{대상 및 방법}

\section{1. 연구 대상}

2013년 6월부터 9월까지 경기도와 인천지역 47곳의 치과 병원 급 19 개 기관, 의원급 28 개 기관 진료실에서 감염되기 쉬운 유닛체 어 등받이, 라이트 손잡이, 타구대 표면에서 멸균된 면봉을 이용하 여 검체를 채취하였다.

\section{2. 연구 방법}

\section{1) 실험균 채취}

치과 병원 - 의원 진료실의 유닛체어 등받이, 라이트 손잡이, 타 구대 표면에서 실험균을 얻기 위해 $10 \mathrm{~cm} \times 10 \mathrm{~cm}$ 로 정한 부분을 멸균 면봉을 사용하여 검체를 채취 한 후 멸균생리식염수 $10 \mathrm{~mL}$ 에 넣은 다음, $4^{\circ} \mathrm{C}$ 를 유지한 상태로 실험실로 옮겼다(Chung, 2015).

\section{2) 실험균 배양과 세균수 측정}

표면의 세균수를 측정하기 위하여 채취한 검체는 $10^{-1}, 10^{-2}$,
$10^{-3}$ 으로 희석하여 준비하였다. 그리고 각각 시료 $100 \mathrm{uL}$ 를 nutrient agar (Difco Co., Le Pont de Claix, France)배지에 분주 하여 멸균 유리봉으로 고르게 펴 바른 후 $35^{\circ} \mathrm{C}$ 에서 48 시간 배양하 였다. 배양한 후 형성된 집락수로 생균수를 측정한 다음 희석배수 를 곱하여 CFU $/ \mathrm{mL}$ (CFU; colony forming unit)로 표시였다. 그리 고 순수분리 배양하기 위해 2회 평판획선배양법으로 계대 배양하 였다.

\section{3) 실험균의 동정}

실험균을 동정하기 위하여 Bergey's Manual (Holt 등, 1994)에 따라순수분리 배양된 균주의 형태와색소 생성능, 점조성 등을 확인 하였으며, 그람염색법으로 그람양성균, 그람음성균 분리와 형태를 구분하였다. 그리고 blood agar (Oxoid Co., Bashingstoke, UK) 배지에 접종한 후 VITEK 2-compact 자동화 동정기(bioMérieux Co., Marcy l'Etoile, France)를 사용하여 그람양성세균 동정용 카 드(GPI), 그람음성간균 동정용 카드(GNI), 그람양성 막대균 동정 용 카드(BAC), 효모 동정용 카드(YBC)로 동정하였으며(Cho 등, 2006), 동정이 어려운 균주는 BBL Crystal 검사법으로 재검사하여 동정하였다.

\section{4) 통계분석}

자료의 분석은 SPSS 18.0 (SPSS Inc., Chicago, IL, USA)을 이용 하였다. 표면의 세균 오염도 분석을 위해 분산분석(one way ANOVA) 및 t-test을 실시하였다.

\section{결 과}

\section{1. 치과 진료실 내 표면의 세균수}

치과 진료실 내 표면의 세균수는 유닛체어의 평균 균체수는 $5.47 \times 10^{3} \mathrm{CFU} / \mathrm{mL}$, 라이트 손잡이에서 $16.28 \times 10^{3} \mathrm{CFU} / \mathrm{mL}$, 타 구대에서 $44.82 \times 10^{3} \mathrm{CFU} / \mathrm{mL}$ 로 측정되었으며, 환자가 치료한 구 강 내 물을 헹구는 타구대가 가장 높게 나타났다(Table 1).

Table 1. Bacterial contamination levels in dental office (Unit: (FU $\times 10^{3} / \mathrm{mL}$ )

\begin{tabular}{lccc}
\hline \multicolumn{1}{c}{ Division } & Mean \pm S.D. & Minimum & Maximum \\
\hline Unit chair & $5.47 \pm 8.89$ & 1.00 & 13.00 \\
Light handle & $16.28 \pm 40.75$ & 1.00 & 20.00 \\
Cuspidor & $44.82 \pm 64.74$ & 1.00 & 200.00 \\
\hline
\end{tabular}

Abbreviation: SD, standard deviation. 


\section{2. 의료기관의 규모에 따른 표면 세균수}

의료기관의 규모에 따른 표면 세균수를 알아보기 위해 병원 - 의 원급으로 나누어 비교 분석한 결과 유닛체어의 평균 균체수는 병원 급 $4.25 \times 10^{3} \mathrm{CFU} / \mathrm{mL}$, 의원급 $6.30 \times 10^{3} \mathrm{CFU} / \mathrm{mL}$ 로 의원급이 높 게 나타났다. 그리고 라이트 손잡이는 병원급이 $17.21 \times 10^{3}$ $\mathrm{CFU} / \mathrm{mL}$, 의원급 $15.65 \times 10^{3} \mathrm{CFU} / \mathrm{mL}$ 로 나타났으며, 타구대는 병원급 $68.95 \times 10^{3} \mathrm{CFU} / \mathrm{mL}$, 의원급 $28.45 \times 10^{3} \mathrm{CFU} / \mathrm{mL}$ 로 병원 급이 높게 검출되었다(Table 2).

\section{3. 환자수에 따른 표면 세균수}

환자수에 따른 표면 세균수를 비교한 결과 유닛체어의 평균 균 체수는 50 99명일 때 $8.44 \times 10^{3} \mathrm{CFU} / \mathrm{mL}$, 라이트 손잡이는 100 명이상일 때 $7.62 \times 10^{3} \mathrm{CFU} / \mathrm{mL}$, 타구대도 100 명이상일 때 $58.84 \times 10^{3} \mathrm{CFU} / \mathrm{mL}$ 로 가장 높게 나타났다(Table 3).

\section{4. 의료기관의 표면관리에 따른 세균 오염도}

표면의 유닛체어의 세균 오염도는 표면소독을 할 경우 $3.43 \times 10^{3} \mathrm{CFU} / \mathrm{mL}$, 소독하지 않을 경우 $2.75 \times 10^{3} \mathrm{CFU} / \mathrm{mL}$ 로 표 면소독을 하는 경우가 높게 나타났으며, 라이트 손잡이, 타구대 표 면은 표면 소독을 하지 않는 경우에 세균 오염도가 높게 확인되었 다(Table 4).

Table 2. Bacterial contamination levels of surfaces depending on the size of dental office (Unit: CFU $\times 10^{3} / \mathrm{mL}$ )

\begin{tabular}{lcccc}
\hline \multicolumn{1}{c}{ Division } & $\begin{array}{c}\text { Dental hospitals } \\
(\mathrm{n}=19) \\
\text { Mean } \pm \text { S.D. }\end{array}$ & $\begin{array}{c}\text { Dental clinics } \\
(\mathrm{n}=28) \\
\text { Mean } \pm \text { S.D. }\end{array}$ & $\mathrm{F}$ & $p$ \\
\hline Unit chair & $4.25 \pm 2.59$ & $6.30 \pm 3.08$ & 0.332 & .568 \\
Light handle & $17.21 \pm 5.82$ & $15.65 \pm 5.20$ & 3.761 & $.050^{*}$ \\
Cuspidor & $68.95 \pm 72.53$ & $28.45 \pm 54.21$ & 4.771 & $.034^{*}$ \\
\hline
\end{tabular}

Abbreviation: SD, standard deviation.

${ }^{*} p<0.05$.

\section{5. 치과 진료실 내 표면 세균 동정}

치과 진료실의 유닛체어, 라이트 손잡이, 타구대 표면에서 순수 분리한 총 균수는 110 균주이며, 이 중 Gram positive 균주는 47.3\%, Gram negative 균주는 52.7\%로 Gram negative 균주가 조금 높게 분포하고 있음을 알 수 있었다. Gram positive 균주 중 $39.2 \%$ 가 알균, $60.8 \%$ 막대균으로 나타났으며, Gram negative 균 주는 $1.7 \%$ 알막대균, $98.3 \%$ 가 막대균으로 확인되었다. Gram positive 균주로는 Bacillus cereus, Bacillus licheniformis, Bacillus pumilus, Bacillus subtilis, Brevibacillus brevis, Corynebacterium bovis, Corynebacterium propinquum, Corynebacterium kutscheri, Leifsonia aquatica, Micrococcus luteus, Kocuria varians, Paenibacilllus macerans, Staphylococcus aureus, Staphylococcus cohnii, Staphylococcus lentus, Staphylococcus warneri로 동정되었으며, 이 중 Micrococcus luteus $10.9 \%$ 로 가장 많이 검출되었으며, 다음으로 Bacillus pumilus, Staphylococcus aureus 균주가 각각 3.6\%로 확인되었다. Gram negative 균주로는 Acinetobacter baumannii, Acinetobacter Iwoffii, Acinetobacter ursingii, Brevundimonas diminuta, Burkholderia cepacia, Chryseobacterium (Flavo.) indologenes (CDC IIb), Comamonas (Pseudo.) testosteroni, Cupriavidus pauculus, Delftia acidovorans, Elizabethkingia meningoseptica, Methylobacterium sp., Ochrobactrum anthropi (CDC Vd-1, Vd-2), Rhizobium radiobacter, Roseomonas gilardii, Shewanella putrefaciens (Alteromonas putrefaciens), Sphin-

Table 4. Bacterial contamination levels of surface according to the number of patients visiting dental office (Unit: CFU $\times 10^{3} / \mathrm{mL}$ )

\begin{tabular}{lccrc}
\hline \multicolumn{1}{c}{ Division } & $\begin{array}{c}\text { YES }(\mathrm{n}=12) \\
\text { Mean } \pm \text { S.D. }\end{array}$ & $\begin{array}{c}\text { NO }(\mathrm{n}=35) \\
\text { Mean } \pm \text { S.D. }\end{array}$ & $\mathrm{t}$ & $p$ \\
\hline Unit chair & $3.43 \pm 2.61$ & $2.75 \pm 2.96$ & 0.670 & .253 \\
Light handle & $6.60 \pm 6.43$ & $6.67 \pm 5.47$ & -0.034 & .487 \\
Cuspidor & $39.94 \pm 82.85$ & $59.35 \pm 57.80$ & 0.751 & .232 \\
\hline
\end{tabular}

Abbreviation: SD, standard deviation.

${ }^{*} p<0.05$.

Table 3. Bacterial contamination levels of surface according to the number of patients visiting dental office $\left(\right.$ Unit: $\left.\mathrm{CFU} \times 10^{3} / \mathrm{mL}\right)$

\begin{tabular}{|c|c|c|c|c|c|}
\hline Division & $\begin{array}{l}<50(n=9) \\
\text { Mean } \pm \text { S.D. }\end{array}$ & $\begin{array}{c}\text { 50-99 }(n=12) \\
\text { MeantS.D. }\end{array}$ & $\begin{array}{c}\geq 100(n=26) \\
\text { MeantS.D. }\end{array}$ & $\mathrm{F}$ & $p$ \\
\hline Unit chair & $4.27 \pm 7.56$ & $8.44 \pm 10.57$ & $4.52 \pm 8.5$ & 1.806 & .178 \\
\hline Light handle & $4.54 \pm 3.92$ & $6.09 \pm 4.50$ & $7.62 \pm 6.45$ & 0.971 & .387 \\
\hline Cuspidor & $22.15 \pm 48.37$ & $31.44 \pm 60.34$ & $58.84 \pm 69.87$ & 1.447 & .246 \\
\hline
\end{tabular}

Abbreviation: SD, standard deviation. ${ }^{*} p<0.05$. 
Table 5. Genus/species of bacteria identified in the dental office

\begin{tabular}{|c|c|c|c|c|c|}
\hline Bacteria & $A^{*}$ & $\mathrm{~B}^{\dagger}$ & $C^{\dagger}$ & Total & $N(\%)$ \\
\hline \multicolumn{6}{|l|}{ Gram positive cocci } \\
\hline Micrococcus luteus & 7 & & 5 & 12 & $(10.9)$ \\
\hline Staphylococcus aureus & 1 & & 3 & 4 & (3.6) \\
\hline Staphylococcus cohnii & & & 1 & 1 & $(0.9)$ \\
\hline Staphylococcus lentus & 1 & 1 & & 2 & (1.8) \\
\hline Staphylococcus warneri & & 1 & & 1 & $(0.9)$ \\
\hline \multicolumn{6}{|l|}{ Gram positive rods } \\
\hline Bacillus cereus & & & 1 & 1 & $(0.9)$ \\
\hline Bacillus licheniformis & & 1 & & 1 & $(0.9)$ \\
\hline Bacillus pumilus & 2 & 1 & 1 & 4 & (3.6) \\
\hline Bacillus subtilis & & & 1 & 1 & $(0.9)$ \\
\hline Brevibacillus brevis & & & 1 & 1 & $(0.9)$ \\
\hline Corynebacterium bovis & 1 & & & 1 & $(0.9)$ \\
\hline Corynebacterium propinquum & & 2 & & 2 & $(1.8)$ \\
\hline Corynebacterium kutscheri & & & 1 & 1 & $(0.9)$ \\
\hline Leifsonia aquatica & & 1 & & 1 & $(0.9)$ \\
\hline Kocuria varians & 1 & & & 1 & $(0.9)$ \\
\hline Paenibacilllus macerans & 1 & & & 1 & $(0.9)$ \\
\hline Gram positive rods & 7 & 4 & 6 & 17 & $(15.5)$ \\
\hline \multicolumn{6}{|l|}{ Gram negative rods } \\
\hline Acinetobacter baumannii & & & 1 & 1 & $(0.9)$ \\
\hline Acinetobacter Iwoffii & & & 1 & 1 & $(0.9)$ \\
\hline Acinetobacter ursingii & & 2 & 4 & 6 & $(5.5)$ \\
\hline Brevundimonas diminuta & 2 & 2 & 1 & 5 & $(4.5)$ \\
\hline Burkholderia cepacia & 2 & & & 2 & $(1.8)$ \\
\hline Chryseobacterium (Flavo.) indologenes (CDC IIb) & & & 5 & 5 & $(4.5)$ \\
\hline Comamonas (Pseudo.) testosteroni & 1 & & & 1 & $(0.9)$ \\
\hline Cupriavidus pauculus & & & 1 & 1 & $(0.9)$ \\
\hline Delftia acidovorans & & & 1 & 1 & $(0.9)$ \\
\hline Elizabethkingia meningoseptica & & & 1 & 1 & $(0.9)$ \\
\hline Methylobacterium sp. & 3 & & 2 & 5 & $(4.5)$ \\
\hline Ochrobactrum anthropi (CDC Vd-1, Vd-2) & & & 1 & 1 & $(0.9)$ \\
\hline Roseomonas gilardii & & & 1 & 1 & $(0.9)$ \\
\hline Shewanella putrefaciens (Alteromonas putrefaciens) & & & 1 & 1 & $(0.9)$ \\
\hline Sphingomonas (Pseudo.) paucimobilis (Ilk-1) & & & 4 & 4 & (3.6) \\
\hline Stenotrophomonas maltophilia & & & 2 & 2 & $(1.8)$ \\
\hline Gram negative rods & 6 & 4 & 9 & 19 & $(17.2)$ \\
\hline \multicolumn{6}{|l|}{ Gram negative coccobacillus } \\
\hline Rhizobium radiobacter & & 1 & & 1 & $(0.9)$ \\
\hline
\end{tabular}

*Unit chair, ${ }^{\dagger}$ Light handle, ${ }^{\dagger}$ Cuspidor.

gomonas (Pseudo.) paucimobilis (IIk-1), Stenotrophomonas maltophilia로 동정되었다. 이 중 Acinetobacter ursingii 5.5\%로 가장 높게 검출되었으며, Brevundimonas diminuta, Chryseobacterium (Flavo.) indologenes (CDC IIb), Methylobacterium sp.가 각각 4.5\%로 나타났다(Table 5).

\section{고 찰}

최근 병원감염에 대한 중요성이 부각되고 있으며, 특히 치과진 료실 내에는 환자 혈액과 다양한 미생물이 증식하고 있는 타액이
진료 시 압축공기의 분사력을 사용하는 시술을 통하여 병원체들이 직경 50마이크로보다 작은 입자인 에어로졸의 형태로 공기 중에 떠 있다가 낙하되어 의료인, 환자, 도구 표면을 오염시킴으로 감염 률을 증가 시킨다는 보고가 있다(Anuradha와 Shikha, 2015).

이에 본 연구는 치과진료실 표면에 존재하는 세균수와 순수 분 리된 세균을 동정하여 원내감염을 일으킬 수 있는 세균을 확인함으 로서 감염경로 차단과 감염관리의 중요성을 인식시키기 위한 목적 으로 진행하였다.

치과진료실 내 표면 세균수는 타구대가 $44.82 \times 10^{3} \mathrm{CFU} / \mathrm{mL}$ 로 가장 높게 측정되었으며, 라이트 손잡이, 유닛체어 순으로 확인되 
었다. 유닛체어의 각 부위별 소독 전의 세균량을 측정한 결과 타구 대가 가장 높게 나타났다. 이 결과는 무영등손잡이, 기구선반, 머리 받침 순으로 관찰된 Park(2012)의 선행연구와 같았으며, 타구대의 세균수가 높게 나온 이유는 환자 치료 후에 구강 내를 물로 헹구면서 나오는 타액과 혈액이 묻어 세균이 증식했기 때문이라고 판단된다. 의료기관의 규모에 따른 표면 세균수를 알아본 결과는 병원급이 의원급보다 높게 측정되었으며, 환자수가 많을수록 높게 나타났 다. 이는 짧은 시간 내에 많은 환자가 같은 진료용 의자를 사용함으 로써 소독 및 청결상태를 준비할 시간적 여유가 없기 때문에 감염 의 위험성이 커졌을 것이며, 진료 시 사용되는 기구의 사용빈도가 많아질수록 다양한 병원체 에어로졸의 수가 증가하기 때문인 것으 로 사료된다.

의료기관의 표면관리에 따른 세균 오염도는 라이트 손잡이와타 구대의 표면 소독을 하지 않는 경우에 세균 오염도가 높았으며, 유 닛체어는 표면 소독한 경우에 더 높게 나타났다. 이와 같은 결과는 세균의 아포까지 멸균할 수 있는 소독제라도 올바른 방법으로 사용 하지 않을 경우에는 일반 세균도 사멸되지 않고 오히려 오염이 확 산될 수 있다는 Jeong 등(2014)의 연구 결과가 본 실험에서도 확인 되었다. 따라서 치과 진료실 표면세균의 오염도를 줄이기 위해서는 소독방법 및 횟수 등 세균수에 영향을 줄 수 있는 감염관리요인 등 에 대하여 연구할 필요가 있다고 판단된다.

치과 진료실에서 치과 치료 시 hepatitis B virus (HBV), hepatitis C virus (HCV), HIV, Pseudomonas, Acinetobacter, Diphteroids, Lactobacilli, Staphylococci, Streptococci, Mycobacterium 등 과 같은 병원체가 간접 - 직접적으로 감염균으로 검출되어 치과의 료진과 환자사이에서 발생되는 교차감염의 심각한 문제를 발생시 키고 있으며(Kugel 등, 2000), 특히 보철물 연마하는 동안 오염된 에어로졸 입자가 장기간 공기에 남아 감염율을 증가시켜 면역저하 환자, 심내막염, 호흡기질환자에게 위험하다는 연구 보고가 있다 (Al-Saadi 등, 2011).

본 연구에서 치과 진료실의 유닛체어, 라이트 손잡이, 타구대 표 면에서 검출된 세균의 종류를 확인한 결과 순수 분리된 총 110 균주 에서 Gram positive 균주는 47.3\%, Gram negative 균주는 52.7\% 로 Gram negative 균주가 조금 높게 분포하고 있음을 알 수 있었 다. Gram positive 균주 중 $39.2 \%$ 가 알균, $60.8 \%$ 막대균으로 나타 났으며, Gram negative 균주는 $1.7 \%$ 알막대균, $98.3 \%$ 가 막대균으 로 확인되었다. 그리고 타구대에서 $50.5 \%$, 유닛체어 $32.1 \%$, 라이 트 손잡이 $18.3 \%$ 순으로 타구대에서 더 많은 균주와 다양한 균주가 검출되었다.

순수 분리 동정된 Gram positive 균주 중 Micrococcus luteus $10.9 \%$ 로 가장 많이 검출되었으며, 다음으로 Bacillus pumilus,
Staphylococcus aureus 균주가 각각 $3.6 \%$ 로 나타났다. 치과 수관과 유닛체어에서 분리된 균주들 중 가장 빈번한 균주가 Micrococcus luteus와 Sphingomonas spp.라는 O'Donnell 등(2006)의 실험 결과와 같이 본 연구 결과에서도 두 균주의 검출이 높게 확인되었 으며, 개인치과진료실 핸드피스, 머리받침대 및 타구통에서 Staphylococcus aureus, Bacillus pumilus 균주가 분리된 Han과 Chun(2004)의 연구결과와 같은 균주가 검출되었음을 확인할 수 있었다.

Staphylococcus aureus는 병원내 감염의 가장 큰 원인 세균으 로 교차감염을 야기하는 매개 역할을 하며, 치과치료 후의 병원내 감염을 유발하는 주요 원인균으로 골수염, 복막염 등 균혈증으로 발생되는 심장판막 조직의 감염은 매우 치명적이라는 보고가 있다 (Min 등, 2007). 또한 서울소재 치과병원 - 의원의 치주염으로 진단 받은 환자의 타액으로부터 채취한 임상검체에서 Staphylococcus aureus의 분리율이 $41.9 \%$ 로 나타났다는 결과와 연관되며(Kim, 2012), Staphylococcus species가 물 분무와 함께 고속 치과드릴 사용 시 치과 실내 공기에서 발견되었다는 연구 보고가 치과치료 시 감염 윈인균임을 입증할 수 있었다(Mansour 등, 2008).

Staphylococcus cohnii ss. urealyticus, Staphylococcus lentus, Staphylococcus warneri 균주는 건강인에게 질병을 일르키는 원 인균으로는 낮은 비율이지만 면역저하 환자에게 감염이 되면 패혈 증, 골수염을 일으키며, 균혈증이 발생한 환자의 혈액배양에서 분 리되는 원내 감염균으로 보고되고 있다(Min 등, 2007).

Micrococcus luteus는 비강, 상기도 호흡기, 구강 점막에서 상재 하는 균주로 뇌막염, 균혈증을 일으킨다고 알려져 있다(Miltiadous 와 Elisaf, 2011).

또한 Bacillus속은 Atlase (1988)에 의하면 정상적으로 대기 중에 $35 \%$ 로 존재하는 세균으로, 치과 진료실에서도 자주 검출되는 균주 로 알려져 있으며(Kedjarune 등, 2000), 기회주의 감염균주이다.

Gram negative 균주에서는 Acinetobacter ursingii $5.5 \%$ 로 가장 많이 검출되었으며, Brevundimonas diminuta, Chryseobacterium (Flavo.) indologenes (CDC IIb), Methylobacterium sp.가 각각 $4.5 \%$ 로 확인되었다.

Gram negative 균주는 세포 외막에 내독소를 함유하는 lipopolysaccharide (LPS)가 존재하고 있으며, 치과 유닛체어의 물에 의해 옮겨지는 가장 중요한 건강 위험 요인이라는 연구 보고 (Szymańskra 등, 2008; Coleman 등, 2009)를 바탕으로 본 실험에 서도 Gram negative 세균수가 더 많이 측정되었고, 세균의 종류도 다양하게 검출된 결과는 치과 진료실의 세균오염의 심각성과 감염 관리의 시급함을 입증한 결과라고 판단된다.

Acinetobacter baumannii, Acinetobacter lwoffii, Acineto- 
bacter ursingii는 병원 내에 오랫동안 서식하다가 면역력이 저하 된 환자에게 결막염, 피부염, 폐렴, 뇌수막염, 패혈증, 심내막염, 복 강 내 감염, 수술부위감염, 요로감염 등의 합병증을 일으키는 전형 적인 병원 감염균이며, 공기와 액체 경계면에서 biofilm 형성하여 의료장비에 부착되어 있다가 감염되기 때문에 문제가 된다는 연구 보고가 있다(Loubinoux 등, 2003; Marti 등, 2011; Horii 등, 2011).

Brevundimonas diminuta, Burkholderia cepacia, Cupriavidus pauculus, Delftia acidovorans 세균들은 대부분이 물에서 분리되 는 균주들이며, 치과 치료 시 상처부위로 전이 감염되면 면역력이 저하된 환자에게 균혈증, 패혈증을 일으키는 중요한 감염균으로 알 려져 있으며, 화학 소독에 저항성이 강하고(Peters와 McGaw, 1996), 항생제 내성 확산에 중요한 역할을 하기 때문에 특히 주의가 필요한 균주로 보고되고 있다(Costerton 등, 2005).

Delftia acidovorans는 Pseudomonas로 분류되는 균으로 치과 유닛의 수관으로 들어오는 물에서 발견되며, 잔류염소에 저항성이 강하고, biofilm을 형성하는 균주로 치과 수술을 받는 환자에게 침 투하여 감염증을 일으킬 가능성이 높은 세균이다(Stampi 등, 1999).

Chryseobacterium indologenes는 자연환경에 널리 분포되어 있으며, 염소소독에도 생존하기 때문에 병원 소독제에도 존재할 수 있어 혈관카테터, 유치장치를 통하여 감염되어 각막염, 패혈증, 폐 렴 등을 일으킨다고 보고되고 있다(Hseuh 등, 1997).

Methylobacteriumsp., Sphingomonas paucimobilis 등도 원 내감염균으로 면역력이 저하된 환자에게 감염되어 균혈증, 패혈증 을 일으키는 원인균주이며(Ryan와 Adley, 2010; Lai 등, 2011), Shewanella putrefaciens균주는 표면 부착력이 있어 의료기기에 부착하여 오염시키거나 금속 표면을 부식시키는 원인균으로 임상 적으로는 궤양과 외상과 같이 피부 파괴로 인한 피부와 연조직 감 염을 일으키고, 빼, 관절염. 수막염, 심내막염을 일으킨다는 보고도 있다(Khashe와 Janda, 1998).

본 연구 결과 치과 진료실 표면에서 확인된 미생물들이 스켈링, 잇몸 수술, 근관 치료, 발치 등의 치료 과정 중 상처가 났을 때 감염 의 위험성이 극대화될수 있음을 알수 있었다. 이에 치과 진료실 표면 세균으로 인한 감염을 예방하기 위해서는 체계적인 감염관리 시스템 과 감염을 차단하기 위한 방법을 모색할 필요가 있다고 판단된다.

\section{요 약}

본 연구는 경기도와 인천지역의 치과 병원급 19 개 기관, 의원급 28 개 기관 진료실의 유닛체어 등받이, 라이트 손잡이, 타구대 표면 의 검체를 채취하여 실험하였다.
우선 치과 진료실 내 표면의 세균수는 타구대 $44.82 \times 10^{3}$ $\mathrm{CFU} / \mathrm{mL}$, 라이트 손잡이 $5.47 \times 10^{3} \mathrm{CFU} / \mathrm{mL}$, 유닛체어 $16.28 \times$ $10^{3} \mathrm{CFU} / \mathrm{mL}$ 로 타구대가 높게 측정되었으며, 의료기관의 규모로 는 병원급이 높게 나타났고, 환자수가 많을수록 타구대에서 세균수 가 높게 측정되었다.

표면 세균 동정 결과는 Gram positive 균주는 47.3\%, Gram negative 균주는 52.7\%였으며, Gram positive 균주 중 Micrococcus luters 10.9\%, Bacillus pumilus, Staphylococcus aureus 균주가 각각 $3.6 \%$ 로 확인되었다. Gram negative 균주로는 Acinetobacter ursingii $5.5 \%$ 로 가장 많이 검출되었으며, Brevundimonas diminuta, Chryseobacterium (Flavo.) indologenes (CDC IIb), Methylobacterium sp.가 각각 4.5\%로 나타났다.

이에 본 연구는 치과 진료실 내 표면 세균 오염도를 측정하고, 세 균의 종류를 확인함으로써 진료실 내 감염관리의 중요성을 인식시 키고, 감염방지에 대한 구체적인 계획 수립의 기초 자료가 될 것으 로 사료된다.

Acknowledgements: None

Funding: None

Conflict of interest: None

\section{References}

1. Al-Saadi AK. Bacterial cross-contamination between clinic \& dental laboratory during polishing procedure of complete denture. Mustansiria Dent J. 2011, 8:288-292.

2. Anuradha P. Shikha S. Aerosols and oral health. Uni J Med Dent Sci. 2015, 3:11-13.

3. Atlase RM. Microbioloty 2nd ed. 1988. p357. Maxwell Macmillan New York.

4. Centers for Disease Control and Prevention. Guidelines for infection control in dental healthcare settings. Recommendations and reports December 19. 2003, 52:1-61.

5. Cho SS, Cheun JW, Jeun CB, Park SM, Jang SJ, Moon DS, et al. A case of Ochrobactrum anthropi infection after using medicinal plants. Korean J Clin Lab Sci. 2006, 38:22-25.

6. Chung JH. Control of Microbes. Korea Health Industry Development Institute. 2015. www.haccpkorea.or.kr/file/downloadFile. last visited on 2015 June 06.

7. Coleman DC, O'Donnell MJ, Shore AC, Russell RJ. Biofilm problems in dental unit water systems and its practical control. $J$ Appl Microbiol. 2009, 106:1424-1437.

8. Costerton JW, Montanaro L, Arciola CR. Biofilm in implant infections: its production and regulation. Int J Artif Organs. 2005, 28:1062-1068.

9. Eom S, Kim GW. Infection control realities and relevant factors in dental hygienists. J Korean Soc Dent Hyg. 2012, 12:379-389.

10. Han JS, Chun GS. A study about the contamination of micro- 
organisms in private dental clinic. Kor J Oral Maxillofac Pathol. 2004, 28:119-134.

11. Holt JG, Krieg NR, Sneath PHA, Staley JT, Williams ST. Bergey' manual of determinative bacteriology. 9th ed. 1994. Williams and Wilkins. Baltimore.

12. Horii T, Tamai K, Mitsui M, Notake S, Yanagisawa H. Blood stream infections caused by Acinetobacter ursingii in an obstetrics ward. Infect Genet Evol. 2011, 11:52-56.

13. Hseuh PR, Teng LJ, Yang PC, Ho SW, Hsieh WC, Luh KT. Increasing incidence of nosocomial Chryseobacterium indologenes infections in Taiwan. Eur J Clin Microbiol Infect Dis. 1997, 16:568-574.

14. Jamshid A, Fatemah A, Ali MA, Rezvan B, Jahangir A, Ali A, et al. Occupational hazards to dental staff. Dent Res J (Isfahan). 2012, 9:2-7.

15. Jeong SY, Choi JH, Kim EK, Kim SM, Son HJ, Cho NH, et al. Actual disinfection and sterilization control in Korean healthcare facilities. J Korean Acad Fundam Nurs. 2014, 21:392-402.

16. Kedjarune U, Kukiattrakoon B, Yapong B, Chowanadisai S, Leggat P. Bacterial aerosols in the dental clinic: effect of time, position and type of treatment. Int Dent J. 2000, 50:103-107.

17. Khashe S, Janda JM. Biochemical and pathogenic properties of Shewanella alga and Shewanella putrefaciens. J Clin Microbiol. 1998, 36:783-787.

18. Kim YS. Genomic typing of $S$. aureus isolated from dental clinics by coagulase and protein A. Kor J Oral Maxillofac Pathol. 2012, 36:269-277.

19. Kugel G, Perry RD, Ferrari M, Lalicata P. Disinfection and communication practices: a survey of U.S. dental laboratories. J Am Dent Assoc. 2000, 131:786-792.

20. Lai CC, Cheng A, Liu WL, Tan CK, Huang YT, Chung KP, et al. Caused by unusual Methylobacterium species. J Clin Microbiol. 2011, 49:3329-3331.

21. Lee JH. A survey of cognition on infection control of the clients in dental hospital. J Korean Soc Dent Hyg. 2013, 13:249-260.

22. Leggat PA, Kedjarune U, Smith DR. Occupational health problems in modern dentistry. Ind Health. 2007, 45:611-621.

23. Loubinoux J, Mihaila Amrouche L, Le Fleche A, Pigne E, Huchon G, Grimont PA, et al. Bacteremia caused by Acinetobacter ursingii. J Clin Microbiol. 2003, 41:1337-1338.

24. Mansour RA, Ali G, Mohammad RMN, Negar FN. Airborne microbial contamination of dental units. Tanaffos. 2008, 7:54-57.

25. Marti S, Nait Chabane Y, Alexandre S, Coquet L, Vila J, Jouenne $\mathrm{T}$, et al. Growth of Acinetobacter baumannii in pellicle enhanced the expression of potential virulence factors. PLoS One. 2011, 6:1-11.

26. Miltiadous G, Elisaf M. Native valve endocarditis due to Micrococcus luteus: a case report and review of the literature. J Med Case Rep. 2011, 5:251.

27. Min JH, Park SN, Hwang HK, Min JB, Kim HS, Kook JK. Detection of methicillin or vancomycin-resistant Staphylococcus aureus from dental hospital. J Korean Acad Conserv Dent. 2007, 32:102-110.

28. O'Donnell MJ, Shore AC, Coleman DC. A novel automated waterline cleaning system that facilitates effective and consistent control of microbial biofilm contamination of dental chair unit waterlines: a one year study. J Dent. 2006, 34:648-661.

29. Park WY. Relative light unit count at the dental environment by use of Flugun and PCMX as a low temperature spray typed sterilization agent [unpublished master's thesis]. 2012. p8. Dankook University, Seoul.

30. Peters E, McGaw WT. Dental unit water contamination. J Can Dent Assoc. 1996, 62:492-495.

31. Ryan MP, Adley CC. Sphingomonas paucimobilis: a persistent Gram-negative nosocomial infectious organism. J Hosp Infect. 2010, 75:153-157.

32. Shin HS. Dental hospital accreditation demonstration project. Korea Institute for Health and Social Affairs. Ministry of Health \& Welfare. 2008, 148:64-75.

33. Stampi S, Zanetti F, Bergamaschi A, De Luca G. Comamonas acidovorans contamination of dental unit waters. Lett Appl Microbiol. 1999, 29:52-55.

34. Szymańska J, Sitkowska J, Dutkiewicz J. Microbial contamination of dental unit waterlines. Ann Agric Environ Med. 2008, 15:173-179.

35. Yun KO. A study on the influence factor to the bacterial contamination in the dental office. [unpublished doctoral dissertation]. 2014, p1-2. Soonchunhyang University, Asan. 